\title{
Guidelines for EFL Teacher Education and Development in the Humachine Era
}

\author{
Aly Abdul Samea Qoura \\ Mansoura University \\ DOI:
}

\section{Introduction}

To keep abreast of the needs and abilities of the Humachine or the ICT age, we need to recruit, reward, train, learn from, and honor a new generation of talented teachers. The foremost importance should be given to successful teacher preparation programs because we ask much more of teachers today than even decade ago. Today teachers are asked to achieve significant academic growth for all students at the same time that they instruct students with ever-more diverse needs. Teaching has never been more difficult, it has never been more important, and the desperate need for more student success has never been so urgent. Are we adequately preparing future EFL teachers to win this critical job?

The technology keeps changing very rapidly so that the language educators will need to advance and improve their technological skills to adapt with the latest updates ICTs. Therefore, the Humachine or the ICT competencies of EFL teachers should be improved. The adaptation to the technology updates takes a longer period and is not an instant process. Starting from the earliest 1990's or even later in the millennium, the pre-service teacher education in
Egypt put a little attention to the importance of technological skills that hindered the language educator from the actual use of ICTs. The teaching industries relied on the teaching-based institutes to fulfill the enormous demand for a professional teacher in many disciplines especially English as a Foreign Language. This condition had an impact on the current education where the existing senior teachers still lack functional technology in instruction. The percentage of senior teachers is still large in numbers so that the teacher regeneration should become the primary focus in any levels of pre-service teacher education.

Within the rapid changes in communication techniques, culture, pedagogy, and developments in knowledge, it is vital that educators are familiar with new educational changes, mainly those changes which are connected to technology. In the digital age, some teachers might be reluctant to change because they feel they are immigrants in the digital world (Prensky, 2001). Change can be accompanied by fear, and thus some teachers might resist changing (Fullan, 2006). In a developing country like Egypt, teachers might feel more 
frustrated because of the digital gap in the country and because of the digital gap with the students. Thus, some teachers fear the use of technology because they see themselves as digital immigrants, whereas their students are digital natives (Rosen 2010).

As Guemide, Benchaiba, \& Bouzar (2012) explain, e-Educators in developing countries are frustrated with two types of digital divide: the digital divide between developed and developing countries and the digital divide between students and teachers. Labas and El Shaban (2014) added that there is a tension between two mindsets within the framework of the digital rise. The first mindset, called Mindset 1 , assumes the digital revolution is just an extension of the industrial revolution. On the other hand, Mindset 2 assumes the world is now totally different from the way it was 30 years ago in terms of thinking and doing. Teachers with Mindset 1 believe there is no urgent need for a change of the educational model and they resist change. Teachers might think they do not need to change, as they succeeded without the digital tools. Change might be more difficult for teachers living or teaching where the digital development has just started to emerge, such as developing countries.

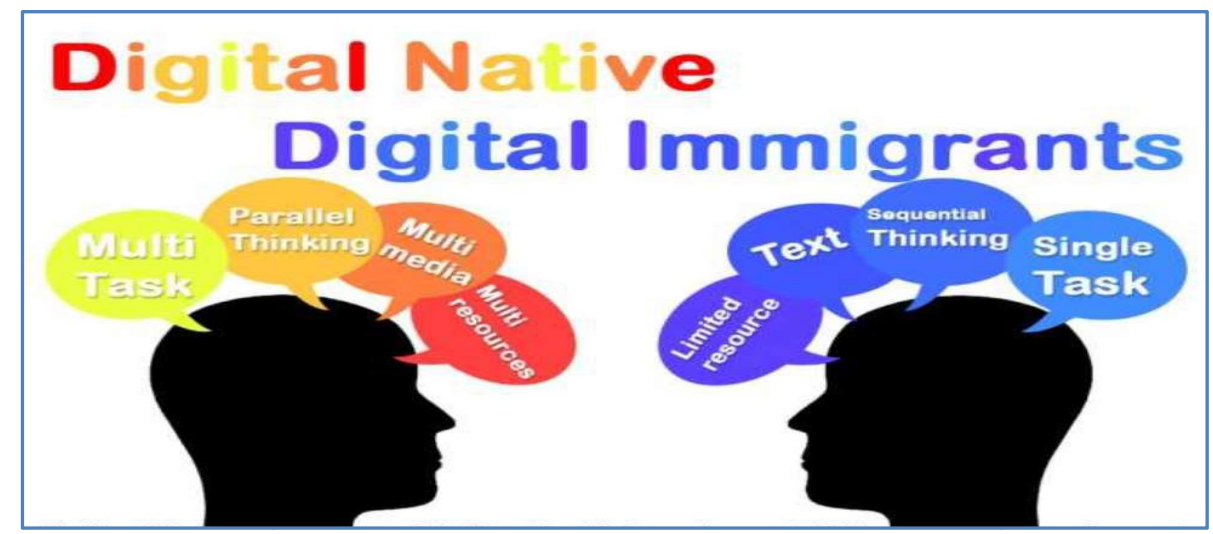

FIGURE (1) http://thesocialmediatrainee.wordpress.com/2010/05/09/digital-natives-vs-digital-immigrants/

This paper focuses on introducing a number of guidelines for the EFL teacher education in the Humachine era. Guidelines are limited to Goals, Skills, Teaching tools and assessment components of teacher education and development. In addition, examples of successful world models are provided. The terms Humachine, ICT, and Digital and $21^{\text {st }}$ century skills are used interchangeably in this paper.
First: Characteristics and Goals of the $21^{\text {st }}$ Century Education

Characteristics: Some important characteristics of digital age:

1. Authentic resources and activities.

2. Online books.

3. Collaboration and communication

4. Hypermedia. 
5. Skills of integration.

6. Just in time learning.

7. Knowledge.

8. Language, style, registers.

9. Multimedia.

10. Netiquette.

11. Online tools.

12. Production.

13. Reading.

14. Spell checks.

15. Text manipulation.

16. Web page publication.

Language skills need to be combined with digital skills in order to be useful in the 21st century. Taking in to account both present and future needs of students will result in curricula and teaching that are up to date, interesting motivating and relevant for digital age.

Goals of the $21^{\text {st }}$ century are many, but salient among them are:

\section{Learner-driven Learning}

At the heart of the learning complex is the individual, the learner, in his and her unique individuality. The recognition of the learner as an active, indeed driving, force in the knowledgelearning process and the self-realization of his/her range of potentialities in that process is a crucial fulcrum for reorienting education.

\section{Learning and Creativity}

Another cardinal goal of the knowledge-learning processes as well as of the educating system is that of developing creativity. Creativity is the potential that every learner carries within himself/herself, waiting to find expression. Learning is what the learner does and cannot be done any other way.

\section{Creative-Methods}

Given the "matrix" of learner-at-center and creativity-as-goal, certain approaches and methods need to be highlighted.

The learners should be active participants in the knowing-learning-teaching process. The degree to which the student is so engaged and involved and committed is the real test of teaching and of the learning environment. Active and participatory learning-teaching shows itself in enhanced ability to think and act independently and creatively.

The knowing-learning process should be presented in contexts in which there is constant interplay of thought and action, theory and application. The interweaving of theory and application promotes the essential ability to adapt knowledge to different situations and to evolve or adopt creative approaches to problem solving. Moreover, the linkage is equally important with the other domains of knowledge, notably values, and real lifeproblems at all levels from local to global.

The ways of knowing are various. The sources of knowing-learning are also various and the methods should constantly expose the students to sources other than the formally organized institutions; namely, learning from fellow learners, from the community, from work sites and importantly from 
active engagement in social action. The central principle governing the methods and models of teaching is that different learners learn different domains of knowledge differently. How to "individualize" the knowing-learning process so that the individual's potential is developed is at the heart of the educational challenge.

These goals necessitate yet a number of skills that help implement them.

\section{Second: Major Skill Components for the EFL}

\section{Teacher in the Humachine Age}

In the digital era, the teacher plays a key role not as a fellow-learner, but also as a link to the knowledge community, or state of the art in that discipline. Hence in additions to general teaching skills, some more skills are needed to be imbibed in a teacher to play his role effectively as a Facilitator of learning. Sharma (2017) recommends a number of skills that are indispensable for all teachers in general and EFL in particular:

\section{Networking Skills}

Networking skills facilitate collaborative learning. Not only students, but the teacher too learn and teaches better in a collaborative learning environment. Collaborative Learning Environment of a teacher consists of many individuals and groups. First of all, it is influenced by those Students whom he/she is teaching for the reason that current society is knowledge society. So, students already have online access to the material,

the teacher wants to teach in the class. Hence they would be having some prior knowledge of the same curriculum influencing and determining what curriculum teacher is taking up in classroom.

Secondly, Teachers of the same subject area who are working in the Institution for the same subject to another sections and classes could be of great help. At the same time, teachers teaching same subject in another schools could be useful in providing knowledge because in digitalized world, it is easy to connect anywhere anytime using Social Media like Skype, We chat, hangouts, yahoo chat, Google chat etc. for sharing of knowledge.

Moreover, if the subject matter is the one of the kind like economic policies, foreign policies of a particular country or comparison of certain Govt. Regulations or case studies, communication with Government Department could be of great help in delivery of right subject matter. Many departments of the Government facilitates online access to its archives containing loads of correct information. In addition to this, Government also provides access to online digital libraries free of cost to make authentic information accessible to all. In addition to that, Communities of practice are a powerful manifestation of informal learning. They generally evolve naturally to address commonly shared interests and problems. By their nature, they tend to exist outside formal educational organizations. Last but not the least, the researchers of that particular 
subject area could be of a great source to know about latest inventions and discoveries in the area.

\section{Communications Skills}

To the traditional communication skills of reading, speaking and writing coherently and clearly, there is a need to add social media communications kills in this digital age to education. These skills include a no. of technological skills like the ability to create a short YouTube video, conducting Webinars, creating online digital library, preparing online Docs, to capture the demonstration of a process, the ability to reach out through the Internet to a wide community of people with one's ideas, to share information appropriately, to give and take feedback, and to identify trends and ideas from everywhere. A teacher can add to his/her knowledge beyond limits with effective communication skills. Social Media Communication skill is one of the prominent skill with which a teacher can reach out to a distant expert of the area or a learner's community to reach out solutions to various problems in his/her daily lesson plans.

\section{Thinking skills}

Of all the skills needed in a knowledge-based society by a teacher, thinking skills like critical thinking, problem-solving, creativity, originality and strategizing are of the utmost importance. Education is increasingly becoming dependent on the creation of new knowledge, new services and new processes to increase competitiveness and generate knowledge. Teachers are actually in a knowledge hub where it depends totally on the efficiency of a teacher to choose the reliable and accurate data from all the available sources.

\section{Nurturing skills}

The teacher in a nurturing approach keeps the needs and demands of the students first and thereby adopt a highly dedicated and unselfish approach to discuss relevant topics. Nurturing skill of a teacher needs them to hold back the transmission and sharing of their knowledge until the student is ready for it and thus denying to many subject experts their own identity and needs to a larger extent. There is a strong emphasis on the teacher focusing on the interests of the student and delivering contents of knowledge and persuading them to connect to the World on empathizing with how the learner approaches learning. Nurturing in this connection helps the learners to grow with the topic by facing different challenges at different levels and thereby understanding the very spirit of the topic and use it strategically.

Ledward and Hirata (2011), state that the 21st century skills are a blend of content knowledge, specific skills, expertise, and literacies necessary to succeed in work and life. They point out that these skills are more than technological literacy and include proficiency in critical thinking, problem solving, communication, and team work. Ultimately, these skills allow people to thrive in the new economy since they help people a) access, 
synthesize, and communicate information; b) work collaboratively across differences to solve complex problems; and c) create new knowledge through the innovative use of multiple technologies.

Upitis, (2014) suggests that creativity in schools gives "students experiences with situations in which there is no known answer, where there are multiple solutions, where the tension of ambiguity is appreciated as fertile ground, and where imagination is honored over rote knowledge" (p. 3). While different countries have offered slightly different interpretations of the scope and nature of 21 st century skills, some common themes emerge:

- A recognition of the changing practices associated with the increase of digital connectivity.

- An emphasis on learning both with and about technology.

- A restatement of the importance of 'basic skills.

- A recognition of the importance of soft skills or 'competences' (WEF, 2015) such as criticality, collaboration and problem-solving.

- A view that flexibility, creativity and innovation and dispositions such as curiosity, 'persistence' or 'grit' (WEF, 2015) are important.

- A recognition that learning continues outside of school contexts, and beyond the span of compulsory education.
- An idea that quite specific skills are needed to compete in the digital economy.

(Adapted from Burnett et al., 2014).

Detailing some teaching competencies and skills can enlarge the list of most needed skills of teachers in the Humachine age. Following are some of these skills and competencies. If we commit to a vision of 21 st century knowledge and skills for all students, it is vital that we support EFL teachers in mastering the competencies that ensure positive learning outcomes for students. These include:

- Successfully aligning technologies with content and pedagogy and developing the ability to creatively use technologies to meet specific learning needs.

- Aligning instruction with standards, particularly those standards that embody $21 \mathrm{st}$ century knowledge and skills.

- Balancing direct instruction strategically with project-oriented teaching methods.

- Using a range of assessment strategies to evaluate student performance and differentiate instruction (including but not limited to formative, portfolio-based, curriculum-embedded and summative).

- Acting as mentors and peer coaches with fellow teachers.

- Designing developmentally appropriate learning opportunities that apply technologyenhanced instructional strategies to support the diverse needs of learners. 
- Applying current research on teaching and learning with technology when planning learning environments and experiences.

- Mastering basic hardware and software operations, as well as productivity applications software, a web browser, communications software, presentation software, and management applications.

- Knowing how, and under which conditions, students learn best, and teachers must anticipate and be able to effectively respond to the difficulties students encounter.

- Thinking Creatively through:

A. Using a wide range of idea creation techniques (such as brainstorming).

B. Creating new and worthwhile ideas (both incremental and radical concepts).

C. Elaborating, refining, analyzing and evaluating their own ideas in order to improve and maximize creative efforts.

- Working Creatively with Others through:

A. Developing, implementing and communicating new ideas to others effectively.

B. Being open and responsive to new and diverse perspectives; incorporating group input

C. Giving feedback into the work.

D. Demonstrating originality and inventiveness in work and understanding the real world limits to adopting new ideas.

E. Viewing failure as an opportunity to learn; understanding that creativity and innovation is a long-term, cyclical process of small successes and frequent mistakes.

- Implementing Innovations through:

A. Acting on creative ideas to make a tangible and useful contribution to the field of EFL.

B. Going beyond basic mastery of skills and/or curriculum to explore and expand one's own learning and opportunities to gain expertise.

C. Demonstrating initiative to advance skill levels towards a professional level.

D. Demonstrating commitment to learning as a lifelong process.

E. Reflecting critically on past experiences in order to inform future progress Teachers' Technological, Pedagogical, and Content Knowledge.

Mishra \& Koehler's (TPACK) framework (2006) provides a theoretical lens to discuss the importance of integrating teachers' technological, pedagogical, and content knowledge in 21st foreign language education. The TPACK framework (Mishra \& Koehler, 2006) is a teacher knowledge framework that describes effective teaching with technology within specific contexts. The interaction of teachers' technological, pedagogical, and content knowledge is what shapes the understanding that teachers should possess to successfully merge technology in their traditional teaching practices. The TPACK structure represented in Figure 1 highlights how technological, pedagogical and content knowledge 
are merged through teachers' knowledge about their subject matter, their understanding of teaching methods and practices, and their familiarity with how information technologies can assist in achieving instructional goals - all within a given context. McGrail (2007) stated that the order in teacher knowledge should be "pedagogy before technology, rather than technology before pedagogy" (p. 81). For that reason, VaOlphen (2008) argued that professional organization such as ACTFL or ISTE play a crucial role in guiding educators to teach in our technological era.

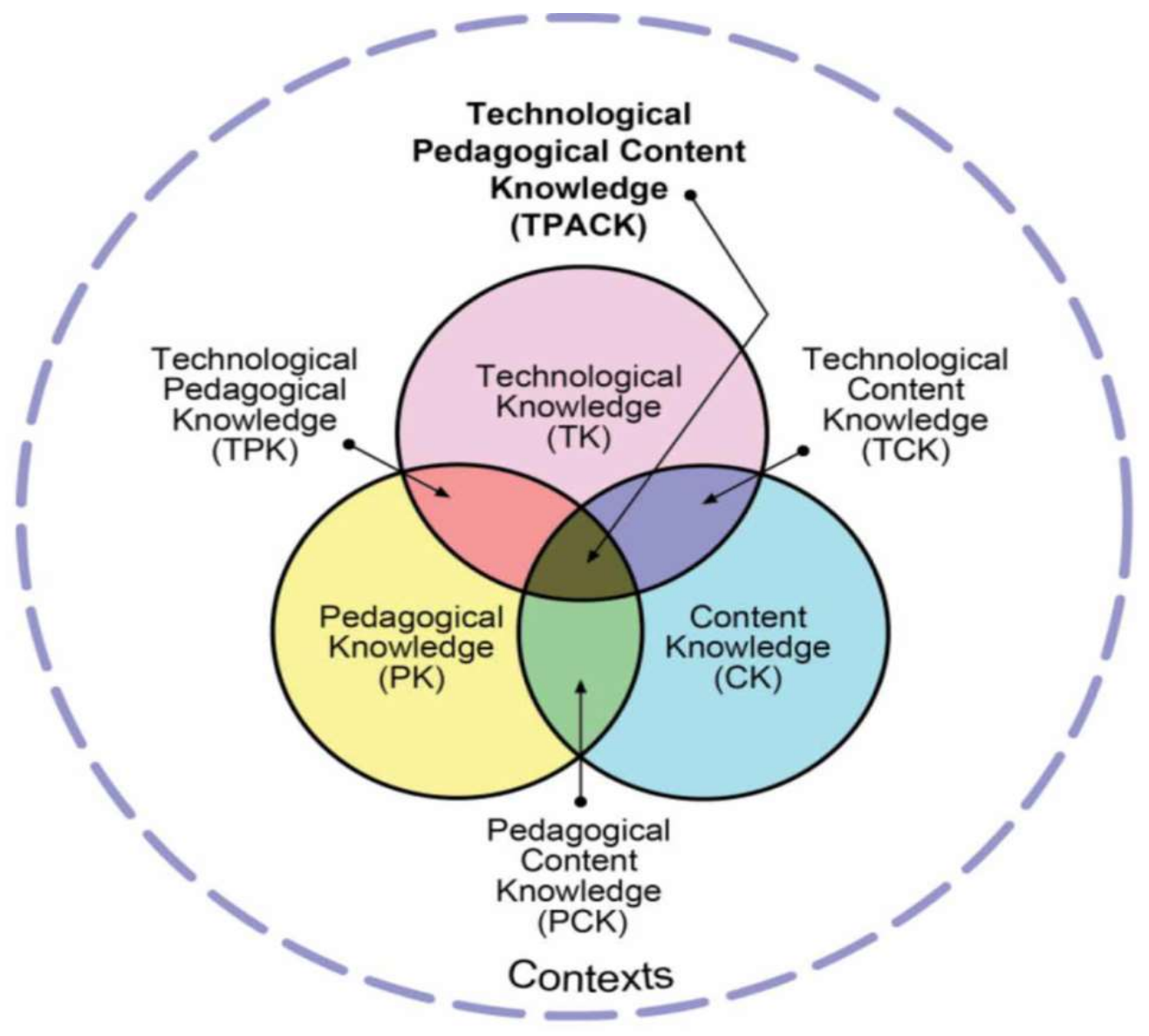

Figure (2) The TPACK framework; from http://tpack.org

\section{New Literacies}

Merchant (2013) identifies five aspects of digital media practices that have implications for how we think about literacy:
- Multimodality: digitally mediated texts work through a combination of images, moving images, hyperlinks, icons, etc. as well as words.

- Online communication has been associated with playful linguistic innovation, e.g. uses of emoticons, abbreviations. 
- Re-mix: many practices involve combining existing media texts in playful ways, e.g. editing existing animations and re-dubbing with new music.

- Participation: practices involve joining with others to share, create and give feedback.

- Connection with known and unknown others: it is now much easier to reach multiple audiences, audiences that are interested and provide a genuine response.

\section{Third: Tools for helping EFL Teaching and}

\section{Learning}

In order for teaches to use the skills and competencies effectively in their in-and-out of the EFL classroom they need a plethora of tools and resources. Boyle (2013) and Ashutosh (2018) provided additional tools for helping educate and develop EFL teachers. These tools are:

1. Speech Peek is an online portal that allows ESL/EFL teachers to create interactive speaking and listening exercises for students to complete and submit remotely.

2. Busy Teacher is an extensive repository of affordable e-books, downloadable classroom posters, informative education articles for ESL/EFL teachers and over 10,000 free printable worksheets in dozens of categories.

3. English Listening Lesson Library Online (ELLLO) contains hundreds of pre-recorded monologues and discussions on an enormous variety of topics, geared to English speakers at six distinct levels of skill from beginner to advanced. ELLLO recruits speakers from more than 60 countries, helping you introduce your students to a variety of different

4. English accents, and some exercises contain comprehension games as learning aids.

5. TEFLnet presents its materials for ESL/EFL teachers in the U.S. and internationally. Features include a worksheet generator, downloadable lesson plans, and a discussion board for teachers.

6. Fun English Games.com is a great resource for ESL/EFL teachers in early childhood education, offering a wide variety of teaching tools aimed at children. Features include a long list online interactive games and printable puzzles, quizzes and worksheets on numerous topics.

7. Tefl tunes uses the principle that music is a great teaching tool and memory aid educators in the ESL/EFL field instruct students on English grammar and topical vocabulary at multiple skill levels.

8. Busuu provides online interactive lessons in English using photos and recordings by native speakers and other types of audio-visual material.

9. Edmodo is an educational tool that connects teachers and students, and is assimilated into a social network. In this one, teachers can create 
online collaborative groups, administer and provide educational materials, measure student performance, and communicate with parents, among other functions.

10. Socrative is a system that allows teachers to create exercises or educational games which students can solve using mobile devices, whether smart phones, laptops, or tablets. Teachers can see the results of the activities and, depending on these, modify the subsequent lessons in order to make them more personalized.

11. Projeqt is a tool that allows you to create multimedia presentations, with dynamic slides in which you can embed interactive maps, links, and online quizzes.

12. Class Dojo is a tool to improve student behavior: teachers provide their students with instant feedback so that good disposition in class is 'rewarded' with points and students have a more receptive attitude towards the learning process. Class Dojo provides real-time notifications to students, like 'Well Done David!' and '+1', for working collaboratively. The information that is collected about student behavior can be shared later with parents and administrators through the web.

13. Story bird aims to promote writing and reading skills in students through storytelling. In this tool, teachers can create interactive and artistic books online through a simple and easy to use interface. The stories created can be embedded in blogs, sent by email, and printed, among other options. In Story bird, teachers can also create projects with students, give constant feedback, and organize classes and grades.

14. Animoto is a digital tool that allows you to create high-quality videos in a short time and from any mobile device, inspiring students and helping improve academic lessons.

15. Kahoot! is an educational platform that is based on games and questions. Through this tool, teachers can create questionnaires, discussions, or surveys that complement academic lessons. The material is projected in the classroom and questions are answered by students while playing and learning at the same time. Kahoot! Promotes game-based learning, which increases student engagement and creates a dynamic, social, and fun educational environment.

16. Boom Writer a great digital tool for collaborative writing. Boom Writer is suitable for children of all ages but especially for the little ones who are still reluctant to write. Boom Writer encourages students to write a story together by voting for each person's version of the story.

17. Explain Everything Explain Everything is all about interaction in a virtual environment. This digital tool allows students and teachers to collaborate on an interactive whiteboard thus 
encouraging group activities. This software can also be integrated with Schoolwork, Dropbox, Evernote, GDrive, OneDrive and more useful apps. With the drag-and-drop options, Explain Everything is super easy and intuitive to work with.

18. Schoology is a learning management system which is free to use and it allows teachers to create and distribute materials, give assessments, track progress, etc. Basically, with Schoology you can do everything that you do in Google Classroom, plus more features. You can organize content much more easily, embed multimedia within the assignment description, record audio or video within the platform, and have a grade book, set completing rules and many more.

19. Pikto chart is a great digital tool which can be used by both educators and students for various educational purposes. This tool allows you to create info-graphics, presentations, posters, and more visual materials. It is perfect for classroom activity, as well as home activity.

20. Google Documents For those of us teaching without Smart boards, Google Docs can be a useful tool when collaborating on a single assignment. You can load up your Google Drive with tons of in-class activities or start a new document on the fly.

21. The Fluent website is an outstanding learning and teaching tool on its own. But for the hungry student it also serves as a great source of meaningful and interesting supplementary materials. Thankfully, the scores of videos, trailers, quizzes and other authentic language learning materials are available as an app to take with you on the go!

\section{Why use digital tools and resources}

Teachers use digital resources for a variety of purposes and in many ways, including:

- As a way to introduce students to a topic

- As part of a teacher lecture or demonstration

- As a stimulus to group or whole-class discussion

- To provide students with access to different text types

- To engage students in activities that are not possible in the classroom

- To allow students to work at their own pace as a review or extension activity.

The digital age yielded e-assessment to help teachers and students improve their achievement and performance. Following is a brief section on eassessment potentials for the EFL teacher that prepares him for the requirements of the $21^{\text {st }}$ century.

\section{Fourth: E- Assessment}

The term e-assessment or digital assessment is variously defined. JISC (2007) define eAssessment as: 'the end-to-end electronic assessment processes where ICT is used for the 
presentation of assessment activity, and the recording of responses' (p. 6).E-assessment as a single term describes a range of learning and assessment activities that have distinct meanings in their own contexts e.g. electronic marking, online assessment, computer-aided assessment and direct on-screen testing are all referred to as eassessment.' It involves the use of digital devices to assist in the construction, delivery, storage or reporting of student assessment tasks, responses, grades or feedback. E-assessment can be undertaken with many devices, such as traditional desktop computers or laptops, with portable communication devices such as smart mobile phones, with digital devices such as iPads or through the use of electronic gaming devices.

E-assessment can use a multitude of formats, including text documents or portable document formats, multimedia formats such as sound, video or images; it can involve complex simulations or games; it can also be undertaken by students in groups or individually and it can occur with large numbers of students in a synchronous or asynchronous manner.

\section{Four Ways of Using Digital Assessment Tools}

1. Gamifying the Answers

One of the most popular tools for digital assessments is Kahoot! This gamification platform helps teachers build the learning process in a form of a game by creating multiple choice questions or using already existing games. The teacher can upload media files and images to create a unique game, or download ready-made stuff. Though every student needs to work on their personal computer to pass the test, this is a great group activity, as all questions are shown on a shared screen and may be discussed if needed. According to the feedback from US teachers, Kahoot! provides $100 \%$ engagement in the class, as students totally plunge into the competitive atmosphere wanting to win.

\section{Giving Instant Feedback}

A great tool for free stuff lovers is Socrative. This software is equipped with various features that can be used by educators for many different purposes. It also includes activities like quizzes, quick questions, exit tickets, etc. Socrative has an intuitive colorful and easy interface and apps for both students and teachers. The tool allows educators to get immediate insight into their student understanding in real-time, as they can create quizzes in seconds and also share them with other teachers.

\section{Tracking Progress}

Plickers is another real-time educational software allowing to get data for an assessment. It is a comprehensive tool that helps teachers understands exactly where their students are in terms of progress. Though Plickers is a serious tool for digital assessing, many students consider it to be a fun game, what makes the studying process even 
easier. The results may be seen in two modes: Students mode and Graph mode. The Graph mode allows a teacher to explore how learners make their decisions, while the Students mode helps learners track their correct and incorrect answers.

\section{Creating Survey-Based Assessments}

A widely-used tool for student assessments is Google Forms. Google Forms allows teachers to create multiple choice questions in the form of a survey and enhance it with images and videos in a few minutes. They can also add collaborators to their Google Forms and work on a survey together.

Dyer (2019) and Lynch (2017) and WatanabeCrockett (2018) provided a long list of these tools and apps for formative assessment success which are considered a synergy for giving teachers and students many opportunities for classroom success. Some of the most salient of these tools are:

1. Animoto - Gives students the ability to make a short, 30-second share video of what they learned in a given lesson.

2. Buncee - A creation and presentation tool that helps students and teachers visualize, communicate, and engage with classroom concepts and ideas.

3. Edueto is a site where teachers can create a variety of online exercises.

4. Flippity is a site that allows teachers to import data from spreadsheets to create a variety of activities.
5. For All Rubrics - This software is free for all teachers and allows you to import, create, and score rubrics on your iPad, tablet, or smart phone. You can collect data offline with no internet access, compute scores automatically, and print or save the rubrics as a PDF or spreadsheet.

6. Go Class Give powerful interactive lessons to kids via their mobile devices.

7. Kahoot: This is a popular free Gamified student-response tool that lets teachers use multiple choice or sequencing questions.

8. Quizalize - A great tool that allows teachers to easily create quizzes and homework for students. Teachers can then see how the students did and identify areas for improvement.

9. Socrative - Exercises and games that engage students using smart phones, laptops, and tablets.

10. Voice Thread - Allows you to create and share conversations on documents, diagrams, videos, pictures, or almost anything. This facilitates collaborative student discussion and work.

\section{Implications for EFL Teacher Practice}

In order for the $21^{\text {st }}$ century skills, competencies, and assessment to be implemented teachers should: 
- Provide leadership in support of designing a School Improvement Plan founded on $21^{\text {st }}$ Century models of learning.

- Pursue creative and innovative teaching practices in your classroom.

- Encourage students to identify their learning interests and offer project based learning opportunities.

- Pursue personalized learning opportunities for your students.

- Share innovative teaching practices with your peers.

- Support collaborative teaching models in your school.

- Take an active role in redesigning learning outcomes to ensure they are relevant to today's students.

- Promote and attend in-service training opportunities on $21^{\text {st }}$ Century learning models, methodologies and digital resources and tools.

- Encourage teacher and student access to digital resources and tools.

- Support modernizing teaching standards to reflect $21^{\text {st }}$ Century learning and teaching reality.

(OECD, 2003).

Fifth; World Example Models for Teacher

Education and Development in the

\section{Humachine Age}

Four successful Models of Teacher education and /development in the digital age are highlighted below

\section{Teacher education in Finland}

Teacher education in Finland has at least four distinguishing qualities:

- Research based. Teacher candidates are not only expected to become familiar with the knowledge base in education and human development, but they are required to write a research-based dissertation as the final requirement for the master's degree. Upper grade teachers typically pick a topic in their subject area; primary grade teachers typically study some aspect of pedagogy. The rationale for requiring a research-based dissertation is that teachers are expected to engage in disciplined inquiry in the classroom throughout their teaching career.

- Strong focus on developing pedagogical content knowledge. Traditional teacher preparation programs too often treat good pedagogy as generic, assuming that good questioning skills, for example, are equally applicable to all subjects. Because teacher education in Finland is a shared responsibility between the teacher education faculty and the academic subject faculty, there is substantial attention to subject specific pedagogy for 
prospective primary as well as upper-grade teachers.

- Good training for all Finnish teachers in diagnosing students with learning difficulties and in adapting their instruction to the varying learning needs and styles of their students.

- A very strong clinical component. Teachers' preparation includes both extensive course work on how to teach - with a strong emphasis on using research based on state-of-the-art practice - and at least a full year of clinical experience in a school associated with the university. These model schools are intended to develop and model innovative practices, as well as to foster research on learning and teaching.

Within these model schools, student teachers participate in problem-solving groups, a common feature in Finnish schools. The problem-solving groups engage in a cycle of planning, action, and reflection/evaluation that is reinforced throughout the teacher education program and is, in fact, a model for what teachers will plan for their own students, who are expected to use similar kinds of research and inquiry in their own studies. The entire system is intended to improve through continual reflection, evaluation, and problem solving, at the level of the classroom, school, municipality, and nation.

Source: OECD (2011a).

\section{The Le@rning Federation, Australia and New Zealand}

A joint venture called The Le@)rning Federation was developed as a major digital content project for Australian and New Zealand schools. The Le@rning Federation developed learning objects for schools as well as learning and content management systems. Some initiatives involved the development of content to meet the curriculum, professional development, and other educational priorities of education systems. The Le@rning Federation began as a major digital content project for Australian and New Zealand schools. It developed specifications for educational soundness and new delivery systems such as web portals, learning management systems, and content management systems. A number of schools implemented major software packages to support these functions. The Le@rning Federation also developed a "Basic E-Learning Tool Set" to provide schools with the basic functionality for managing learning objectives, until comprehensive learning content management systems could be implemented within jurisdictions. State and territory education authorities also operated various initiatives for providing their schools with digital content. And yet another vision from the USA.

\section{1:1 Initiatives - one student, one digital device} Handhelds (more affordable than notebooks) opened the door to $1: 1$ in education. Over the last 
decade, more and more public and private stakeholders across the world have been supporting 1:1 initiatives in education. In the United States, the state of Maine was the first to equip every 7 th and 8 th grade student and every 7 th through 12 th grade teacher state-wide with personal access to learning technology. The One Laptop per Child initiative (OLPC) initiative may have inspired the development of a new category of low-cost devices, net books, which, together with smart phones, seem to be the technological drivers of contemporary initiatives. The decreasing cost of ICT devices, combined with the lighter weight of laptops and increasing availability of wireless connectivity, have been the main enablers of the rapid spread of such initiatives and their implementation at a broad scale. Despite the limitations of available evidence, research supports the positive impacts of 1:1 initiatives in writing and ICT skills. Source: Valiente (2010).

\section{China's Research-based Philosophy}

The authorities in the Shanghai province of China emphasize giving prospective teachers the skills they will need for action research, and their method for improving their education system over time relies on research performed by teachers. As in Finland all students in Shanghai are expected to perform at high levels and teachers are expected to make sure that no student, literally, will be allowed to fall behind. This makes it essential that teachers identify students who are just beginning to

flounder, diagnose the problem, and have the skills and knowledge needed to create a large and constantly updated reservoir of solutions for the student performance problems they have diagnosed.

To conclude this leads to the question: What teacher preparation programs are needed to prepare graduates who are ready to teach well in a 21 stcentury classroom? One of the key challenges for the teaching profession is to strengthen the "technical core" of its professional practices which requires the development of educational ecosystems that support the creation, accumulation and diffusion of this professional knowledge. Such ecosystems need to draw on four sources: innovation and knowledge inspired by science (research and evaluation); innovation inspired by firms (entrepreneurial development of new products and services); innovation and knowledge inspired by practitioners (teachers, school heads); and innovation inspired by users (students, parents, communities). While the evidence base in this area is only emerging, this chapter has identified a range of promising practices in these areas. Source: Schleicher (2012)

\section{References}

Anas. I \& Musdariah, A. (2018). Being an ETeacher: Preparing the ESL Teacher to Teach English with Technology JELTL (Journal of English 
Language Teaching and Linguistics). Vol. 3 (1) 4156.

Ashutosh, C. (2018). Digital Education Tools For Teachers And Students. https://elearningindustry.com/digital-educationtools-teachers-students

Boyle, J. (2013). 8 Great Online Resources for ESL/EFL Teachers. Retrieved January 15, 2019, at 4 PM. From http://emergingedtech.com

Burnett, C. (2016). The Digital Age and Its Implications for Teaching and Learning, Cambridge Primary Review Trust.

Coyle, E. (2017). 5 strategies for more effective online assessments. Retrieved on Feb. $18^{\text {th }}, 2019$, at 10:55 PM. From: http://learningscience.co.uk/blog/

Crisp, G. (2011). Teacher's Handbook on eAssessment. Transforming Assessment Available at: www.transformingassessment.com

Dyer, K. (2019). 75 Digital tools and apps Teachers can use to support Formative assessment in the Classroom. Retrieved on Feb. $2^{\text {nd }}, 2019$, at 5 PM. From: https://www.nwea.org.

Fullan, M. (2006). The New Meaning of Educational Change. 4th Ed. Columbia University: Teachers College Press.

Herbele, V. (2010). Multimodal literacy for teenage EFL students. Cadernos de Letras, 27, 101-116. Retrieved January 21, 2019, at 10 AM. From http://www.letras.ufrj .pdf
Fandiño, Y. (2013). 21st Century Skills and the English foreign language classroom: A call for more awareness in Colombia: Gist Education and Learning Research Journal, 7, 190-208.

Jeong-Bae Son. (2011). Online Tools for Language Teaching. $\quad$ http://www.teslej.org/wordpress/issues/volume15/ej57/ej57int/

JISC (2007). Effective practice of assessment. Retrieved on Oct. $10^{\text {th }}, 2018$, at 9 AM. From: http://www.ljmu.ac.uk/lid/lid docs/Effective Practic e in Assessment.pdf.

Kocoglu, Z. (2019). Exploring the technological pedagogical content knowledge of pre-service teachers in language education. Procedia Social and Behavioral Sciences (1) 2734-2737.

Labas, L \& El Shaban, A(2014) Teacher Development in the Digital Age Teaching English with Technology, 13(3), 53-64

Lynch, M. (2017). Edtech tools that make formative assessment a breeze. Retrieved on Jan.12th, 2019, at 11 PM. From: https//www.thetechedvocate.org.

Ministry of Education (2016). Towards Defining 21st Century Competencies for Ontario. Available on the Ministry of Education website at www.ontario.ca/education.

Mishra, P. \& Koehler, M. J. (2006). Technological pedagogical content knowledge: A new framework for teacher knowledge. Teachers College Record, 108(6), 1017-1054. 
Nazikian, F. \& Park, J. (2016). How to Develop "2 $1^{\text {st }}$ Century Skills" in Foreign Language Education. Japanese Language and Literature, 50(2), 347-373.

Niess, M. L. (2005). Preparing teachers to teach science and mathematics with technology: Developing a technology pedagogical content knowledge. Teaching and Teacher Education, 21(5), 509-523.

Nia Kurniawati N, Maolida E, and Anjaniputra A (2018). The praxis of digital literacy in the EFL classroom: Digital immigrant vs digital-native teacher Indonesian Journal of Applied Linguistics, Vol. 8 No. 1, May 2018, pp. 28-37

Organization for Economic Co-operation and Development (2003). Education at a Glance. Retrieved December 12, 2018, at 6 PM. From www.oecd.org

Padmovathi, G. (2013). English Teaching and Learning in the Digital Age. International Journal of Modern Engineering Research (IJMER) www.ijmer.com Vol.3, Issue.1, Jan-Feb. 2013 pp116-118.

Prensky, M. (2001). Digital natives, digital immigrants. On the Horizon 9 (5). Retrieved Jan., 29, 2011, from http://www.marcprensky.com/writing/Prensky\%2020Digital\%20Natives,\%20Digital\%20Immigrants\% 20-\%20Part1.pdf
Prensky, M. (2012). From Digital Natives to Digital Wisdom: Hopeful Essays for $21^{\text {st }}$ Century Learning. Thousand Oaks, CA: Sage Publications. Corwin Rosen, L. (2010). Rewired: Understanding the iGeneration and the Way They Learn. New York: Palgrave Macmillan.

Schleicher, Andreas (ed.) (2012), "Preparing teachers to deliver 21st-century skills", in Preparing Teachers and Developing School Leaders for the $21^{\text {st }}$ Century: Lessons from around the World, OECD Publishing, Paris.

Sharma, M. (2017). Teacher in a Digital Era. Global Journal of Computer Science and Technology: G Interdisciplinary Volume 17 Issue 3 Version 1

Shulman L. S. (1987). Knowledge and teaching: foundations of the new reform. Harvard Educational Review, 57, 1-22.

Son, J. (2011). Online tools for language teaching. TESL-EJ, 15(1).

UNESCO (2018) UNESCO ICT Competency Framework for Teachers, United Nations Educational, Scientific and Cultural Organization, 7, place de Fontenoy, 75352 Paris 07 SP, France.

UTIFEN: Use of Technology for Mobile Teacher Training in Niger.

http://www.utifen.org:81/wp/

https://itunes.apple.com/us/app/leafsnap-foripad/id433522683?mt=8

https://www.duolingo.com/ 
https://itunes.apple.com/us/app/elsa-speak-accentreduction/id1083804886? $\mathrm{mt}=8 \&$ ign-mpt $=$ uo\%3D4

https://www.turnitin.com/

http://researchnetwork.pearson.com/digital-dataanalytics-and-adaptive-learning

http://www.learnsmartadvantage.com/about/

https://www.classcraft.com/fr/ https://www.coursera.org/

Massive Open Online Courses

http://alloprof.qc.ca

Warschauer, M. (2003). Dissecting the 'digital divide': A case study in Egypt. The Information Society, 19(4), 297- 304. 